\title{
Krakatau caldera deposits: revisited and verification by geophysical means
}

\author{
Izumi Yokoyama
}

The Japan Academy, Ueno Park, Tokyo, Japan

Article history
Received September 2, 2013; accepted September 2, 2014.
Subject classification:
Krakatau caldera, Parasitic cones, Caldera deposit, Drillings at calderas, S-wave attenuation, Vp/Vs ratio.

\section{ABSTRACT}

One of the differences between volcanic craters and calderas is that the latter bottoms are flatways filled with caldera deposit with lower density in comparison to country rocks. The 1883 Krakatau eruption affords us important knowledge on caldera formation even if it was not observed with modern sophisticated instruments. First, volcanic activities of the Krakatau Islands before and after the 1883 eruption are reexamined: previous suppositions involving a caldera-forming eruption of the proto-Krakatau prior to 1883 proved to be unsupported by the bathymetric topographies and gravity anomalies on and around the Krakatau Islands. Then, Anak Krakatau is interpreted as a parasitic cone of the main Krakatau volcano. As supplementary knowledge to discussion of caldera deposits, the results of drillings at several calderas in Japan and Mexico are introduced. Mass deficiency of the caldera deposit at Krakatau caldera is estimated by the gravity anomaly observed there and converted to probable volume with suitable density. For quantitative examination of the subsurface structure beneath the Krakatau complex, spatial distributions of seismic S-wave attenuation and Vp/Vs ratios have been already studied by temporary seismological observations and their results have been published. The high ratios of $\mathrm{Vp} / \mathrm{Vs}$ observed approximately at Krakatau caldera may be attributable to the caldera deposit that is low density and contain much water. As additional remarks, a zone having both the characters, S-wave attenuation and zones of relatively high $\mathrm{Vp} / \mathrm{Vs}$ ratio, may be a probable magma reservoir centering at a depth of about $10 \mathrm{~km}$.

\section{Introduction}

The 1883 eruption of Krakatau volcano in the Sunda Straits, between Java and Sumatra islands, Indonesia (inset in Figure 1), and its destructive effects have been long disputed among many researchers. However, we still have unsettled problems in the field of volcanology such as identifying reliable distribution of the ejecta, their volume, modes of the explosions, origins of tsunamis, and subsurface structure left by the explosions. Especially, in the study of caldera formation, the following two facts are still the obstacles to the above unsettled dispute to be ever challenged.

a) The explosions progressed within dense explosion clouds and zero visibility impaired accurate scientific reports of the events.

b) Seismometers were not available around Krakatau volcano at that time, and only a tide gauge, a pressure meter and magnetometers had been operated in Batavia located about $150 \mathrm{~km}$ from the volcano.

The present author will try to synthesize the results from recent geophysical observations on and around the Krakatau Islands, such as marine gravity surveys, measurements of $S$-wave attenuations and seismological tomography to determine $\mathrm{Vp} / \mathrm{Vs}$ ratios, all relating to magma reservoirs or caldera deposits beneath Krakatau caldera.

\section{Volcanic activities at the Krakatau Islands before and after the 1883 eruption}

2.1. Assumptions on geological structure of the pre-1883 Krakatau complex

Verbeek [1885] and Escher [1919] proposed an assumptive history of the Krakatau complex and focused on a large central andesitic cone measuring about 15 $\mathrm{km}$ in basal diameter and probably $2000 \mathrm{~m}$ a.s.1. According to their account, this proto-Krakatau erupted violently resulting in the formation of a caldera and later the three islands of Krakatau, Verlaten and Lang were formed on its rim. The present author doubts their speculations for the following reasons.

1) Generally, caldera-forming eruptions do not tend to occur from the same vent and the magma activity would migrate to another sites finally to form a composite caldera of larger dimension. As shall be discussed in the next subsection, and shown in Figure 3, Rakata, Danan, Perbuwatan and Anak Krakatau are equally the parasites of the 1883 Krakatau volcano 


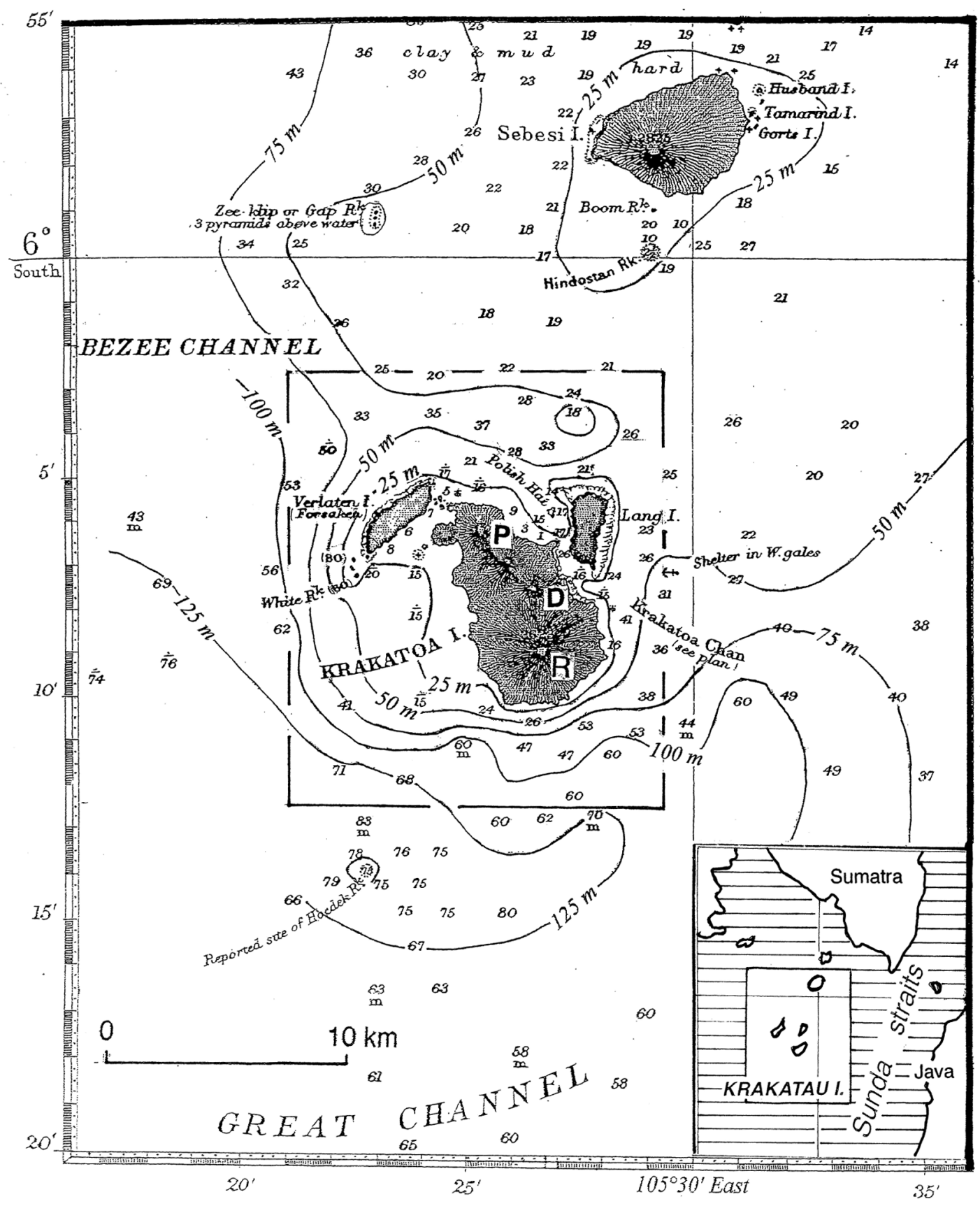

Figure 1. British Admiralty Chart of the Krakatau area surveyed in1868. Spot depths are given in fathom ( 1 fathom $=1.83 \mathrm{~m})$, and isobaths are added every $25 \mathrm{~m}$ by the present author. $R$ denotes Rakata, $D$ Danan and $P$ Perbuwatan. An inset shows the Krakatau Islands in the Sunda Straits after the 1883 eruption and a square frame at the center of the main figure approximately indicates the areas of Figures 2 and 3.

which was the remnants of explosion activity of the proto-Krakatau. Its explosion center was located under the sea and reactivated in the 1883 eruption.

2) We do not find any trace of a larger caldera or depression around the Krakatau Islands in the bathymetric chart surveyed in 1868 (Figure 1) which was reproduced from the report of Wharton [1888]. In this figure, the bathymetric contours were newly added every $25 \mathrm{~m}$ intervals by the present author. In fact, the circular bathymetric contours around the islands do not suggest the remains of a large depression. We can infer from these topographies that the three islands existing prior to 1883 were situated on a submarine plateau of the remnants of the proto-Krakatau.

As shall be mentioned in Subsection 4.1, we find no low gravity anomaly indicating the existence of a pre-1883 caldera. Instead the anomaly at the periphery shows an increase toward the center of the islands (Figure 2). Based on these data, we infer that there existed the basement of proto-Krakatau volcano until the 1883 eruption.

An alternative scenario to the Verbeek and Escher model is as follows: on the proto-Krakatau, no caldera had been formed, but periodic and destructive volcanic activities culminated and transformed this single landmass into the three islands or separate blocks (Krakatau, 


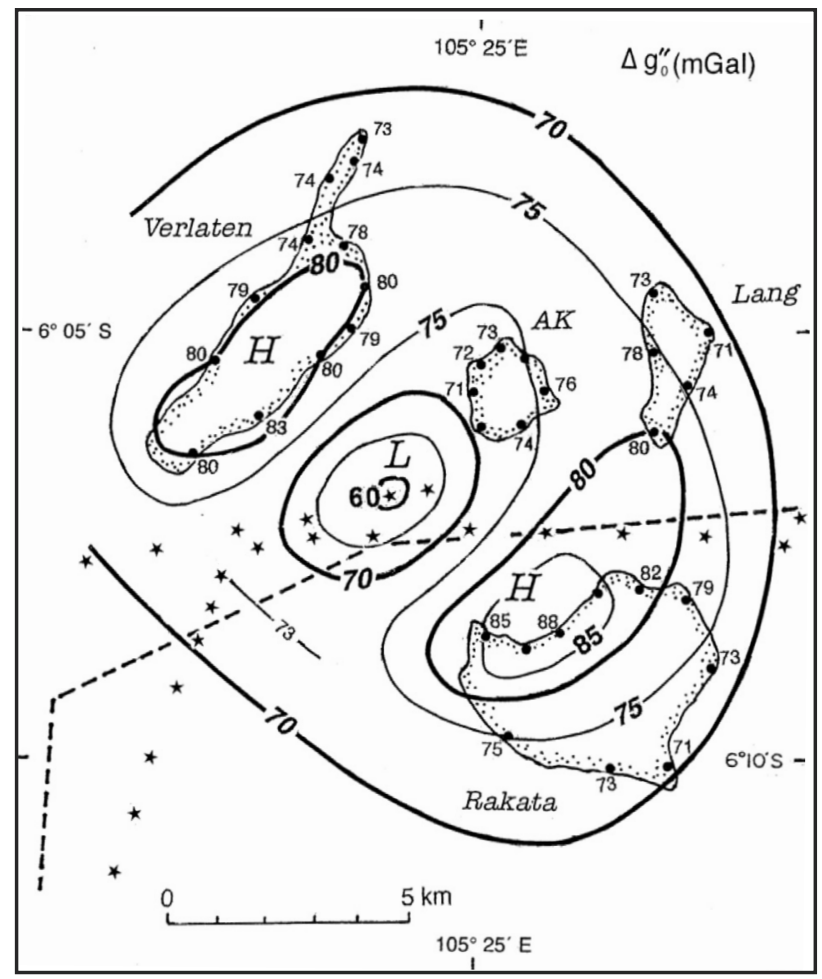

Figure 2. Bouguer gravity anomaly in mGal on and around the Krakatau Islands. Land anomalies are compiled from Yokoyama and Hadikusumo [1969] and Deplus et al. [1995] and more than 40 gravity points have been occupied. Marine anomalies are compiled from Deplus et al. [1995]: $\star$ symbol: the Krakatau cruise of 1985; Broken line: the Corindon cruise of $1983 . H$ and $L$ denote relatively high and low gravity anomalies, respectively.

Verlaten and Lang islands) before the 1680 activity that was reported to have been at some parasitic craters and not so violent. The main vent may have been always located at the same post as the center of the 1883 eruption. Subsequently, on Krakatau Island, a basaltic volcano (Rakata) formed, followed by andesitic parasitic cones (Danan and Perbuwatan volcanoes). Originally these three are all parasites of the proto-Krakatau. The British Admiralty Chart reproduced in Figure 1 shows the shape of the Krakatau Islands as of 1868. After 2 centuries of low activities since 1680, a caldera-forming eruption took place in 1883, and the three parasitic cones on Krakatau Island were partially or totally destroyed. Then, 44 years later (1927), Anak Krakatau appeared at a "parasite gap" [Yokoyama 2013] between ex-Danan and ex-Perbuwatan among the Krakatau complex (Figure 3).

To discuss the subsurface structure of volcanic areas, gravity analyses are useful. Yokoyama [1963] classified calderas from the standpoint of their subsurface structure into 2 types: high-gravity-anomaly type and low-gravity-anomaly type. To determine the basement structure of the Krakatau complex, gravity surveys on and around the islands have been repeated as follows:

First, Yokoyama and Hadikusmo [1969] measured gravity on the Krakatau Islands with a land gravimeter and obtained Bouguer gravity anomalies in the Potsdam system published in 1930. The results indicated funnel-shape caldera deposits of about $5 \mathrm{~km}^{3}$ in volume on the base of the gravity anomaly. These deposits, named "fallbacks" by Yokoyama [1981] were produced by explosions and composed of the juvenile ejecta and lithic fragments of pre-caldera volcanic edifices. Yokoyama [1987] supplemented the 1968 survey with the data obtained in 1982 and the final results were reduced to International Gravity Standardization Net 1971 (IGSN71) [Morelli et al. 1974].

Later, Deplus et al. [1995] carried out marine gravity and bathymetric surveys, and confirmed a relative low gravity anomaly amounting to $20 \mathrm{mGal}$ at the center of the caldera. They discussed the subsurface structure of the Krakatau complex and analyzed the gravity anomaly by adopting various density models. Their models revealed the geometry of the dense substratum of the proto-Krakatau and the presence of a collapsed structure filled with low-density material beneath the caldera.

The present author compiled the gravity data obtained during a period 1969 1995 on and around the Krakatau complex and figured a tentative distribution of the Bouguer anomaly as shown in Figure 2.

Although this gravity anomaly map contains some ambiguity due to an insufficient number of gravity

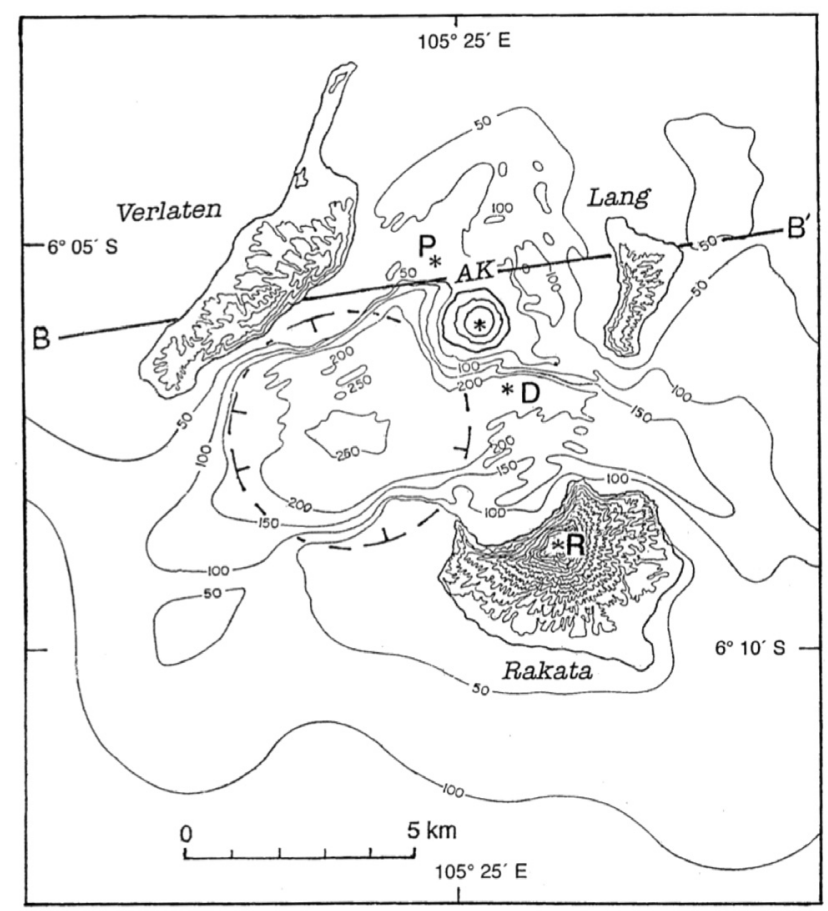

Figure 3. Topographic and bathymetric chart on and around Krakatau. Both the contours and isobaths are drawn every $50 \mathrm{~m}$. A circle of broken line is an assumed caldera rim. B-B' line is the datum line in Figure 5b. $A K$ denotes Anak Krakatau, $R$ Rakata, $D$ Danan, and $P$ Perbuwatan. 
points, a relatively low anomaly is evident at the caldera area. The gravity anomaly decreases by $15 \mathrm{mGal}$, roughly from 75 to $60 \mathrm{mGal}$, caused by the 1883 eruption. As mentioned above, Krakatau is a caldera of the low-gravity-anomaly type. The gravity distribution around the Krakatau Islands may have been faintly influenced by appearance of Anak Krakatau after 1927. It is noticeable that the low anomaly caused by the 1883 caldera is surrounded by a high anomaly increasing from 70 to $80 \mathrm{mGal}$. In all likelihood, the high anomaly was produced via the remains of the basement of the proto-Krakatau. Based on these results, we may conclude that the proto-Krakatau had not formed a caldera and been destructed into the three remnants by violent eruptions long before 1680 , and that the remaining topographies were roughly the same as observed in 1868 as shown in Figure 1.

A low gravity anomaly or its trace suggesting the pre-1883 caldera is not present in Figure 2. If a pre-1883 caldera had been formed, we would have expected to observe a relatively low gravity anomaly larger than 20 $\mathrm{mGal}$ over an area of $5 \mathrm{~km}$ in diameter. The low gravity anomaly originated from the 1883 eruption overlaps the region where the high gravity anomaly due to the basement is located. As previously mentioned, Rakata, Lang and Verlaten Islands may be the remnants of the violent eruptions, and two acidic parasitic cones, Danan and Perbuwatan were added to Rakata ultimately forming Krakatau Island before 1680.

\subsection{Relationship between Krakatau caldera and Anak} Krakatau

Although there were no eyewitnesses of the 1883 eruption, Stehn [1929] believed the main vent of the 1883 eruption to be at the central and deepest point of the depression formed by the eruption. The craters of Danan and Perbuwatan (Figure 1) were expelling ashes before the climatic eruption. The main central vent of the proto-Krakatau volcano may have been in roughly the same location as the vent of the 1883 caldera mentioned above, while Rakata, Danan, Perbuwatan and Anak Krakatau appear to be parasites formed in a circular pattern and branched from the main conduit which is connected to a deep magma reservoir. Before the 1883 eruption, the main conduit was located under the sea. Furthermore, this hypothetical main vent may have produced submarine explosions that would easily explain the occurrence of huge tsunami in this location. Contacts between magma and seawater may have accelerated the strength of the eruptions but were not substantial enough to cause the large eruptions in 1883. The original motive force of the 1883 eruption should mainly be attributed to magmatic forces.
The 1883 eruption produced a caldera measuring about $5 \mathrm{~km}$ in diameter with rather flat bottom as shown by a circle of broken line in Figure 3 prepared by the Volcanological Survey of Indonesia in 1970. Later Deplus et al. [1995: Figure 7] compiled a detailed bathymetric chart of the Krakatau area. In both the charts, caldera bottom is relatively flat ranging from $200 \mathrm{~m}$ to $250 \mathrm{~m}$ b.s.l. and the caldera walls are not so steep; for example, the steepest slope of the northern wall is measured as about 25 degrees that mean a gentle slope. This may suggest that the caldera wall is a funnel-shape as already suggested by Yokoyama [1963].

Anak Krakatau is a parasite of Krakatau volcano. We know empirically that parasites are monogenetic: that is to say, they would exert volcanisms for a cycle of the existing magmatic activity and we cannot anticipate its length of life. However, we cannot exclude the possibility that Anak Krakatau may grow up with magmatic evolutions and finally cause climatic explosions forming a caldera. Such activities should develop to form a larger composite caldera combined with the present Krakatau caldera.

Camus et al. [1987] discussed the petrologic evolution of the Krakatau complex and emphasized periodicity of volcanic activity. An eruptive cycle culminating in the 1883 dacite, resulted from magmatic differentiation in the magma reservoir, and the cycle of Anak Krakatau has been characterized by a change of the eruption products from basaltic to dacitic in the 1981 eruption. However, they added that the more ancient cycles are not so clearly defined. The fact that the periodicity in magmatic differentiation was maintained by the 1883 eruption means that evolution of the magma in Krakatau magma reservoir was not disturbed by the 1883 eruption. As mentioned above, no caldera was formed on the proto-Krakatau, and the present author deduces that such magmatic evolution is not always related to caldera-forming eruptions and admits the possibility that dacitic magmas may cause devastating explosions.

Prior to discussion of the formation process of Anak Krakatau, parasitic eruptions shall be reviewed in general terms according to the work of De la CruzReyna and Yokoyama [2011] and Yokoyama [2013]. If we assume the presence of a point dilatation model beneath a volcano, surface deformations can be interpreted as the result of upward principal stresses while fractures at the surface are explained by both the theories of maximum stress and of maximum shearing stress.

At an active crater, directly above the pressure source, only upward force is exerted. When magma drains back leaving conduits free of volcanic material, or when the blockaded conduit is not strong enough, 
the magma can break out the crater bottom. Since the processes described fit the usual model of polygenetic eruptions, the theory of maximum stress is applicable.

Magma cannot always penetrate through a strongly solidified central crater. Instead, under various conditions, low depth magma has a tendency to proceed obliquely toward the mechanically weakest point. By applying the theory of maximum shearing stress, we can access this situation. Material mechanics shows that the critical stress is equal to a half of the value of horizontal differential stress and is represented as:

$$
1 / 2\left(\sigma_{\mathrm{x}}-\sigma_{\mathrm{z}}\right)
$$

where $\sigma_{\mathrm{x}}$ and $\sigma_{\mathrm{z}}$ denote the principal stresses. And the maximum shearing stress occurs across a plane whose normal bisects the angle between the greatest and least principal stresses. In the following, we assume a simple model beneath a horizontal plane: a uniform expansion of a spherical pressure source $P=P_{0}$ at depth $D$ and with intensity $a^{3} P_{0}$ (Figure 4). After some analytical treatments, the critical stress (1) proves to have a positive or negative maximum value corresponding to:

$$
r= \pm \sqrt{6} D / 3= \pm 0.82 D \text {, or } D=1.22 r
$$

Therefore, the hypothetical volcano body receives the maximum horizontal differential stress at radial distance $r= \pm 0.82 \mathrm{D}$, or at the point where the dip angle of the pressure source from the fracture point at the sur-

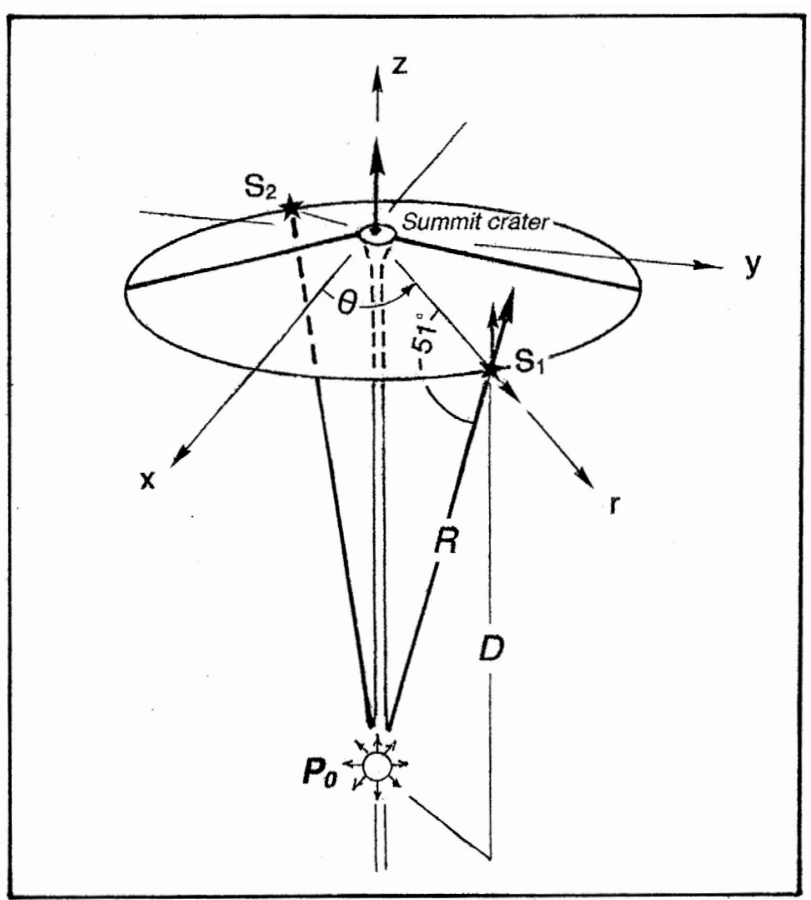

Figure 4. Shear fracture model for formation of parasitic vents. $P_{0}$ : point source of dilatational pressure; $S_{1}$ and $S_{2}$ : a pair of parasitic vents. face is $51^{\circ}$. Consequently, the shear fracture should take place in a radial direction on the surface or along the slope Theoretically we expect the maximum horizontal differential stress to exist at $r= \pm 0.82 \mathrm{D}$ or diagonally opposite to the center of the volcano though declination $\theta$ cannot be estimated quantitatively because some parameters in the above discussion are not determinable on the actual volcanoes. The particular conditions of each volcano may affect how these pairs of fracturing points react. When a parasitic vent is formed at one fracture point, usually the other pair point doesn't fracture probably due to stress concentration at the former. Twin parasites are very rare but we know some examples such as Sakurajima, Japan during the last three large eruptions [Yokoyama 2013], Fogo, the Cape Verde Islands in 1951, Hekla, Iceland in 1970, and Tyatya, Kuril in 1973.

Whether magma breaks out from main crater or from parasitic vents depends on the condition of the existing main crater and strength of the material concerned. Alternatively, the balance between magma pressure and rock strength at the sites may influence the outcome. Compressive stress affects the strength of main craters at the summits and parasitic sites have both compressive and shear stresses. Thus, rock strength plays an important role in the above determination. Compressive rock strength is roughly in the order of $100 \mathrm{MPa}$ and shear strength is roughly in the order of $10 \mathrm{MPa}$ [Jaeger 1964: Tables 3 and 4]. The balance between upward compressive force against the strong compressive strength and shear force against the weak shear strength determines the location of the fracture. At present the balance cannot be estimated quantitatively because some parameters mentioned above are not accurately determinable. Furthermore, based on past records, we cannot expect eruptions to exclusively follow summit or parasitic eruption model. Parasitic eruptions have occurred simultaneously with summit eruptions on some volcanoes. In such cases, volcanic activities should be rather energetic.

In case of Krakatau caldera, the center of the 1883 eruption has been concluded to be at the deepest point among the three islands as shown in Figure 3. The eruption site of Anak Krakatau in 1927 is located at a distance of about $3.5 \mathrm{~km}$ from the center. Hence, the branch point from the main conduit is assumed to be roughly $4.3 \mathrm{~km}$ deep by Equation (2), and is represented by the star symbol in Figure $5 \mathrm{~b}$ and the main conduit may be possibly connected with a magma reservoir. The dispositions of Anak Krakatau and its junction of the conduit are similar to those of disappeared parasites, Rakata, Danan and Perbuwatan, and support the hypothesis of cyclic magma activity of the Krakatau complex in sequence of basalt, andesite and dacite [Camus et al. 1987]. 


\section{Evidence of caldera deposits found by drillings at some calderas in Japan and Mexico}

From a geophysical standpoint, Yokoyama [1963] classified calderas as high- and low-gravity-anomaly types according to the density of the deposits: high-density deposits are basaltic lavas and mainly found at the caldera bottoms while low-density deposits are mainly silicic pyroclastic ejecta distributed around calderas and partly fallbacks at the caldera bottoms. The former are created by gravity subsidence while the latter origin is unsettled partly because we have scarcely experienced caldera formation of this type except the 1883 Krakatau, the 1912 Katmai and the 1991 Pinatubo eruptions. Krakatau caldera belongs to the latter type: its deposit is totally located below sea level, and no drilling results are available. More specific information about the kind of material and its configuration situated are necessary. The geology of Krakatau caldera itself has not been well studied. However, we have obtained valuable data from some other calderas located above sea level by geological and geophysical methods and also by drilling operations. The results obtained by drillings at some calderas of the latter type in Japan and Mexico shall be mentioned in the following:

Kuttyaro, Hokkaido: This is one of the largest calderas in Japan, measuring $20 \mathrm{~km}$ in diameter with a caldera lake. Yokoyama and Tajima [1959] measured gravity on the frozen lake and found relative low anomalies amounting to about $40 \mathrm{mGal}$ at the maximum. The gravity anomaly is attributed to the caldera deposit of low density and its depth is estimated at about $2 \mathrm{~km}$ at the center. Nishida and Yokoyama [1965] examined physical properties of the cores drilled at its center of the caldera. The drilling reached $1 \mathrm{~km}$ deep. Those cores are generally porous and pumiceous and the majority is agglomerates partly welded tuff, and there is also a small quantity of andesite lava.

Nigori-gawa, Hokkaido: This is a small caldera, 3 $\mathrm{km}$ in diameter. Relative low gravity anomaly is $6 \mathrm{mGal}$ at the maximum. Ando [1983] and Kurozumi and Doi [2003] studied this caldera. Since 1974, 37 exploratory drillings had been done within the caldera; 4 drillings reached depths over $3 \mathrm{~km}$. On the basis of these results, they determined the structure of this caldera as to be a steep funnel-shape filled with fallbacks, and concluded that the origin of the caldera was explosions.

Aso, Central Kyushu: This is a large caldera measuring about $20 \mathrm{~km}$ in diameter, and there are active craters on the summit. Gravity anomalies in and around the caldera observed by Komazawa [1995] suggest that Aso caldera is composed of 5 depressions, small and large in diameter. The relative low gravity anomaly was about $20 \mathrm{mGal}$. There have been several drillings, shal- low and deep, within the caldera. Shallow drillings near the northern and southern caldera rims detected the basements at around $400 \mathrm{~m}$ deep, and deeper drillings near the center of the caldera penetrated a thick layer of welded pyroclastic flow deposits at a depth of $1.5 \mathrm{~km}$. These results indicate that Aso caldera is funnel-shaped and its caldera deposit is composed of fallbacks.

Aira, Southern Kyushu: This caldera is located at the northernmost part of the Kagoshima bay and measures about $20 \mathrm{~km}$ in diameter and gravity anomaly reaches about $40 \mathrm{mGal}$ relatively low at the center. A drilling site is at the western shore of the island of Sakurajima volcano that is a post-caldera cone roughly $3 \mathrm{~km}$ inside from the assumed caldera rim. The drilling reaches a depth of $810 \mathrm{~m}$ b.s.l. According to Aramaki [1977], almost all drilled cores are composed of tuff, welded tuff and pyroclastic deposits.

La Primavera, Mexico: This measures $13 \mathrm{~km}$ in diameter, and formed about 95,000 years B.P. Since 1980, the Comisión Federal de Electricidad, Mexico has drilled 13 geothermal wells reaching depths of 668 to $2986 \mathrm{~m}$ around the center of the caldera. The caldera deposits are mainly pyroclastics (Tala tuff) and partly admixed with lithic tuff layers. Beneath the caldera deposits, there are the basements of compact granite at a depth of about $3 \mathrm{~km}$. Yokoyama and Mena [1991] determined the structure of the caldera by reviewing data from the drilling results and gravity anomalies composed of two relative lows amounting to 14 and $9 \mathrm{mGal}$. The caldera structures were assumed to be about 1.5 and $1 \mathrm{~km}$ deep, respectively.

Conclusively, the results of sufficiently deep drillings carried out at the above calderas verify that the caldera deposit is underlain with basement rocks and the basements prove to be possibly funnel-shaped. And there is no evidence that caldera-forming eruptions destroyed the basements which could collapse into magma reservoirs. Caldera deposits tend to be composed of pyroclastic and lithic material of low density. Furthermore it has been established by these studies that magma reservoirs don't exist directly beneath the calderas of low-gravity-anomaly type.

\section{Geophysical studies of subsurface structure of Krakatau caldera}

Immediately after the 1883 eruption, bathymetry records taken around the islands were improved but geophysical studies of the 1883 eruption of Krakatau volcano and of the subsurface structure of the newly formed caldera may have begun in 1980's. As technology developed, various methods have been applied to study the subsurface structure of the Krakatau complex and even now new projects are continuing. It is neces- 
sary to review the past interpretations and to summarize the present developments of the studies.

\subsection{Gravity anomalies and volume of the caldera de-} posit

In the previous Subsection 2.1, the gravity anomaly observed on and around Krakatau caldera is utilized to examine the subsurface structure of the pre-1883 Krakatau complex. In this subsection, it shall be applied to estimate volume of the caldera deposit.

Verbeek [1885] and his successors had not paid attention to the caldera deposit in their studies. In the case of the Krakatau caldera, the caldera deposit is located beneath the sea. By utilizing gravity anomalies in this region, the present author [Yokoyama 1981] estimated the volume of the caldera deposit. According to the results of drillings at several calderas, caldera deposits are usually composed of pyroclastic ejecta and disrupted material of pre-caldera volcanoes (lithic fragments). Such caldera deposits have low density in comparison with country rocks and have been labeled as "fallbacks" by Yokoyama [1981] as mentioned before, and he proposed a subsurface model adopting the density contrast $300 \mathrm{~kg} / \mathrm{m}^{3}$. It is true that assumptions of the density contrasts have much ambiguity.

In the present paper, the distribution of Bouguer anomalies is modified as shown in Figure 2 on referring to the results of the marine gravity surveys carried out by Deplus et al. [1995]. In the figure, two high anomalies exceeding $80 \mathrm{mGal}$ coincide with Verlaten and Rakata Islands, respectively, due to the basements of the proto-Krakatau. A low gravity anomaly amounting to a maximum of $-15 \mathrm{mGal}$ is due to the caldera deposit of low density deposited by the 1883 eruption.

In general, gravity anomalies may be interpreted differently according as different assumptions on density contrasts and distribution of source material, and therefore the results should have some ambiguities. Actually Deplus et al. [1995] discussed gravity data at the wider area including Krakatau caldera and showed different models of the deeper structure of the caldera by adopting different assumptions. Here, the present author is concerned only with the volume of the caldera deposit and later will take the results of drillings at various calderas into consideration. Thus, the mass anomaly $\Delta M$ at the caldera area is related to gravity anomalies with the Gauss's theorem:

$$
\Delta M=\frac{1}{2 \pi k^{2}} \iint \Delta g(x, y) d x d y
$$

where $k^{2}$ denotes the gravity constant. In the present case, $\Delta M$ is graphically obtained at about $2 \pm 0.5 \times 10^{12} \mathrm{~kg}$ above a region covering approximately $20 \mathrm{~km}^{2}$. As in- troduced previously, drillings have revealed that caldera deposits are usually funnel-shaped and comprised of relatively low-density fallbacks resulting from vesiculations and fragmentations. Uniquely exploded ejecta composed of juvenile and lithic material had also fallen into the 1883 Krakatau caldera, mixing with seawater during the repeated explosions. These circumstances influence how density contrast between the basement and caldera deposits is estimated.

Estimation of densities of various material related to caldera formation is rather ambiguous. When seawater penetrates into the fallbacks, material density increases according to porosity of the deposit and accordingly the density contrast decreases more than usual. Hitherto we have assumed densities of the basements and the deposits at land calderas as 2400 and $2100 \mathrm{~kg} / \mathrm{m}^{3}$, respectively. When the dry deposit has a porosity of $10 \sim 20 \%$, a density contrast decreases to 150 $\mathrm{kg} / \mathrm{m}^{3}$ on an average by saturation with water. Consequently the bulk volume of the deposit may be calculated as $(2 \pm 0.5) \times 10^{12} \mathrm{~kg} / 150 \mathrm{~kg} / \mathrm{m}^{3}=13 \pm 3 \mathrm{~km}^{3}$, though we have ambiguity of the density contrast. If this volume is converted to an inverted circular cone or funnel shape with a base covering the same area as the caldera (a circle of $5 \mathrm{~km}$ in diameter), its maximum depth is about $2 \mathrm{~km}$ as a rough standard.

In this case, it is rather difficult for us to locate magma reservoirs by analyses of gravity anomalies observed on the Krakatau Islands because the anomaly due to the caldera deposit predominates over that caused by the possible presence of deeper magma reservoir. To discuss the deeper structure by utilizing gravity anomalies, gravity surveys should cover a wider area in order to detect anomalies of larger wavelength.

To express the structure of Krakatau caldera, we adopt Figure 5 that is composed of two planes: (a) is a horizontal plane at a depth of $2 \mathrm{~km}$ deep while (b) is a vertical plane passing $B-B$ ' line shown in Figure 3 . The caldera deposit of Krakatau is schematically shown with a circle of $5 \mathrm{~km}$ in diameter in Figure $5 \mathrm{a}$ and with a dotted part in Figure 5b: the volume of the deposit is about $13 \mathrm{~km}^{3}$ and its configuration is schematically expressed in conical or funnel shape on consideration of the results of drillings discussed in Section 3.

\subsection{Seismological observations searching for subsurface} liquid parts

Seismicity in volcanic areas is closely related to the activities of the volcanoes and the corresponding subsurface structure.

The 1883 eruption: The seismic activities that accompanied the 1883 eruption of Krakatau were not instrumentally observed. Yokoyama [2001] examined the 
(a)
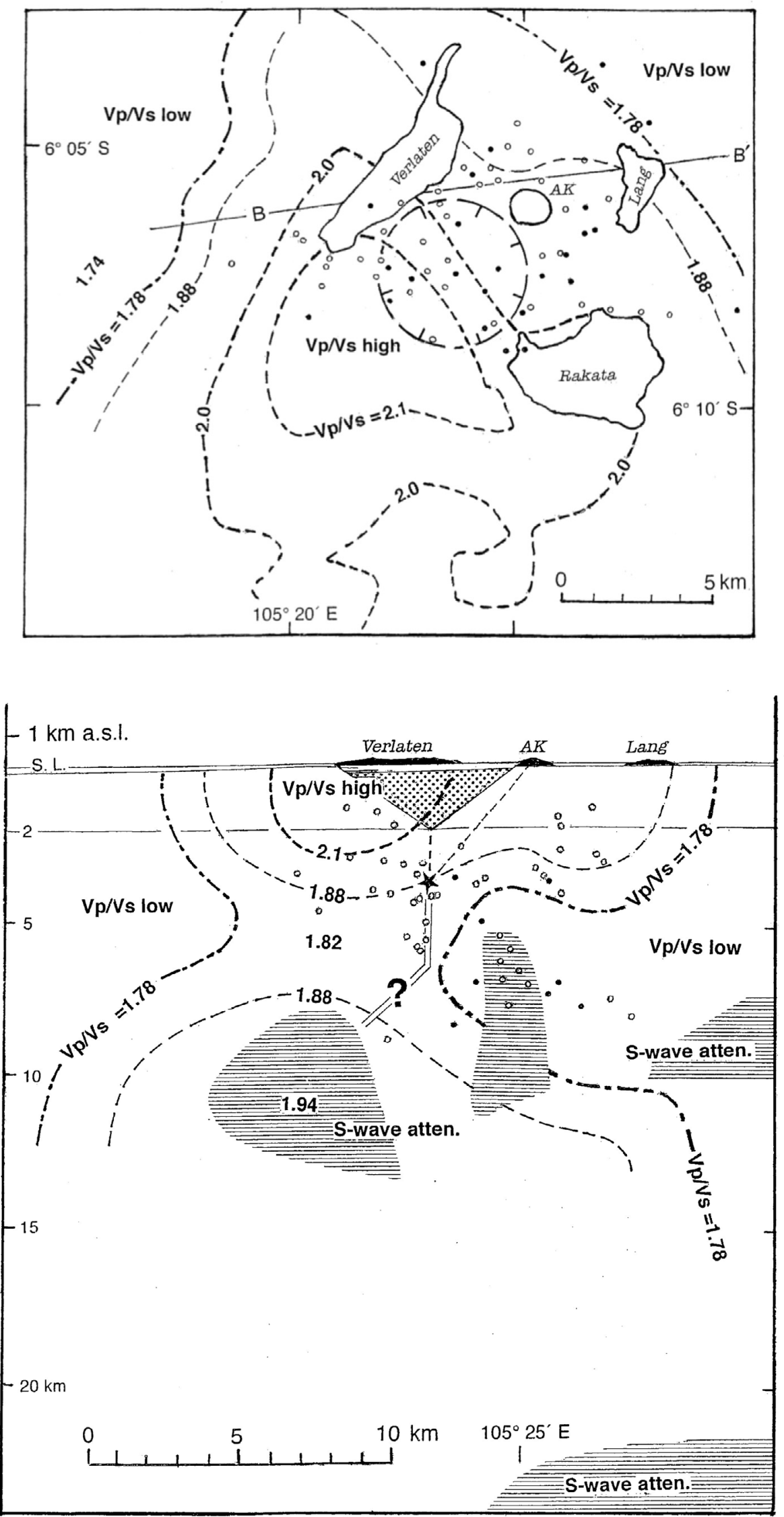

Figure 5. Seismological parameters determined by the temporary observations. The epicenters and hypocenters analyzed by Harjono et al. [1989] and Jaxybulatov et al. [2011] are approximately plotted and denoted by solid and open dots, respectively. AK denotes Anak Krakatau. Distribution of the Vp/Vs ratios are obtained by Jaxybulatov et al. [2011] and that of the S-wave attenuations by Harjono et al. [1989]. (a) Distribution of $\mathrm{Vp} / \mathrm{Vs}$ ratios at the horizontal plane at a depth of $2 \mathrm{~km}$ b.s.l. A circle of broken line is an assumed caldera rim. (b) Distributions of $\mathrm{Vp} / \mathrm{Vs}$ ratios and S-wave attenuations (striped parts) projected on a vertical plane shown by B-B' datum line in Figure 5a. Dotted part: assumed caldera deposit shown schematically; Star symbol: branch point of the vent for Anak Krakatau from an assumed main conduit. 
relationship between the maximum distances of seismic perceptibility and the intensity in MM (modified Mercalli's scale) of the Krakatau earthquakes felt at some towns along the Sunda Straits. He determined the magnitudes of the earthquakes occurring in the 1883 eruption to be no larger than Magnitude 5 by examination of the magnetograms figured by magnetic needles at a magnetic observatory in Jakarta, not seismograms. Generally speaking, magnitudes of volcanic earthquakes accompanied with explosions are usually smaller than $\mathrm{M}$ 5 , although volcanic earthquakes are occasionally enhanced into the range of $\mathrm{M} 7$ by large volcanic eruptions such as M 7.0 in the 1912 eruption of Katmai [Abe 1992]. In case of the Krakatau eruption accompanied with earthquakes of a maximum magnitude of M 5 , volcanic energy may have dispersed mainly in the explosive state and have not contributed as much energy to the earthquakes during caldera formation.

Seismicity obtained by temporary seismological observations: Some of the epicenters or hypocenters around the Krakatau complex which were determined by Harjono et al. [1989] during the summer of 1984 and by Jaxybulatov et al. [2011] for 8 months of 2005 2006 are approximately plotted with solid and open circles, respectively in Figure 5. Distributions of seismometers and analyzing methods as well as seismometer units were not consistent between both surveys, however both could only place seismometers on land, not in the sea. Thus, we may roughly get an idea about the seismicity around the Krakatau complex. The data suggests that the caldera deposit doesn't accumulate elastic energy. One of the characteristic properties of magma reservoirs is fluidity of their contents. In seismological observations around volcanoes, this property should be revealed in particular phenomena such as S-wave attenuations and high $\mathrm{Vp} / \mathrm{Vs}$ ratios. Harjono et al. [1989] set up 10 temporary seismic stations on the both sides of the Sunda Straits and one on Anak Krakatau, all being equipped with a single vertical seismometer. Wave paths were examined from 14 local earthquakes occurring in the summer of 1984 and two bodies of shear-wave attenuation were detected near the Krakatau complex. Some of their results [Harjono et al. 1989: Figure 8b] are schematically reproduced in Figure 5b: several zones of S-wave attenuation were detected beneath the Krakatau Islands, but all were located at the depths deeper than $2 \mathrm{~km}$, and hence they don't appear in Figure $5 \mathrm{a}$. Most probable $S$-wave attenuating zones were detected at between $6 \sim 14 \mathrm{~km}$ deep as shown by striped zones in Figure 5b, and further a voluminous zone was detected at a larger depth of about $22 \mathrm{~km}$, extending eastwards.

Jaxybulatov et al. [2011] carried out temporary seismometric observations at 14 onshore stations on the Krakatau Islands and the coasts of Java and Sumatra. During about 8 months of 2005 2006, more than 700 local earthquakes were recorded, and by using the results, tomographic inversions for $\mathrm{P}$ and $\mathrm{S}$ wave-velocities and for the $\mathrm{Vp} / \mathrm{Vs}$ ratio were performed. They determined the distribution of $\mathrm{Vp} / \mathrm{Vs}$ ratio in a square of $25 \mathrm{~km}$ side centering Krakatau caldera in the map, and to a depth of roughly $15 \mathrm{~km}$. Some of their results are also schematically reproduced in Figure 5 where the epicenters or hypocenters are denoted by hollow circles. From the surface to a $4 \mathrm{~km}$ depth, they observed $\mathrm{Vp} / \mathrm{Vs}$ ratios higher than 2.1 (according to them, a maximum of roughly 2.2) in the adjacent zone of the caldera, and interpreted this as an indicator of the presence of material with partially molten and/or high fluid content. We do not expect more than a scarce amount of molten magma to exist at such a shallow depth after a caldera forming eruption. On the other hand, one of the zones of S-wave attenuation located approximately $10 \mathrm{~km}$ deep beneath the Krakatau Islands shows a rather high value (1.94) of $\mathrm{Vp} / \mathrm{Vs}$ : this zone may contain the magma reservoir that provoked the 1883 eruption.

Jaxybulatov et al. [2011] explained that their network configuration and the distribution of the events (the origins of shallow seismic activities all originated on the east side of the caldera) were not favorable for high quality tomographic imaging. Considering this, we may deduce that the zone of high $\mathrm{Vp} / \mathrm{Vs}$ ratio mentioned previously nearly coincides with the caldera deposit of Krakatau complex. From another viewpoint, their network configuration was especially suitable to detect the caldera deposit.

As mentioned in Subsection 4.1, a subsurface model of Krakatau caldera is created on the assumption that the caldera deposit has density difference of $150 \mathrm{~kg} / \mathrm{m}^{3}$. The present author is inclined to attribute the local and anomalously high values of $\mathrm{Vp} / \mathrm{Vs}$ ratio to the caldera deposit saturated with seawater. Although the zone of the highest $\mathrm{Vp} / \mathrm{Vs}$ ratio doesn't strictly coincide with the caldera deposit zone shown by a dotted part in Figure $5 \mathrm{~b}$, the above rationale may be legitimate considering the challenging situation in which high-quality tomographic imaging took place.

An anomalously high $\mathrm{Vp} / \mathrm{Vs}$ ratio higher than 2.1 has been reported by laboratory measurements. For example, Carmichael [1982] mentioned that compacted "globigerina ooze" (a kind of slime) had the ratio of 2.23 under pressure of $512.0 \mathrm{~kg} / \mathrm{cm}^{2}$.

It is rather difficult for us to calculate with precision the actual state of fallbacks in the 1883 Krakatau eruption because the eruption was so tremendously vi- 
olent, effectively blocking visibility. Eyewitnesses could not approach the event from the sea. However, we theorize that a large amount of ejecta composed of pyroclastics and lithic material fell chaotically into the caldera depression located in the sea during or after repeated gigantic explosions; if this is the case, the caldera deposits of Krakatau may have kept a large amount of seawater and remain saturated even now.

The origin of the caldera deposits continues to be unknown. At many calderas in Japan and Mexico, we have obtained much knowledge about caldera deposits by drillings in these locations as discussed in Section 3: in these instances along with many others, caldera deposits are usually composed of low density fallbacks deposited in funnel-shaped craters.

Synthetic images of the subsurface structure of Krakatau caldera are summarized in Figure 5 as already discussed above: Figure $5 \mathrm{a}$ is a horizontal section at a depth of $2 \mathrm{~km}$, on which the shallow $\mathrm{Vp} / \mathrm{Vs}$ ratios and all epicenters are projected but the area of S-wave attenuations are not because they are located deeper than $2 \mathrm{~km}$. In this projection, the region of highest $\mathrm{Vp} / \mathrm{Vs}$ ratio partly overlaps on the caldera area. As discussed above, the high value of $\mathrm{Vp} / \mathrm{Vs}$ ratio may evidence the watery caldera deposit. Figure $5 \mathrm{~b}$ is a vertical section along B-B' line and shows all the main geophysical features including a schematic profile of the caldera. It is noticeable that the region of the highest $\mathrm{Vp} / \mathrm{Vs}$ ratio partly overlaps on the caldera deposit as well as in Figure 5a. In this projection, Anak Krakatau is hypothetically interpreted as a parasite derived from a magma reservoir of the Krakatau complex. Harjono et al. [1989] determined several zones of S-wave attenuation, one of which was located at a depth about $9 \mathrm{~km}$ directly beneath the Krakatau complex. On the other hand, Jaxybulatov et al. [2011] detected a zone of relatively high $\mathrm{Vp} / \mathrm{Vs}$ ratio roughly at the same zone of Swave attenuation. This zone may be a possible magma reservoir.

\section{Conclusion}

The Pre-1883 Krakatau complex: We don't know of any clear examples of repeated caldera-forming eruptions at the same vent though our observation period is not so long. The topographies and gravity anomalies observed on and around the Krakatau Islands suggest that there was no Krakatau caldera before 1883 .

Anak Krakatau is a parasite: It is plausible that a shallow depth $(\sim 10 \mathrm{~km})$ magma body supplied magmas to the Krakatau complex, causing violent explosions in 1883. Also, we can infer that Anak Krakatau branched from this main conduit at a depth of about $4 \mathrm{~km}$ where is likely to be shallower than the magma reservoir. This model agrees with the fact that the periodicity of magmatic differentiation in the magma reservoir was not disturbed by the 1883 eruption.

Caldera deposit: Existence of caldera deposit is already affirmed by the results of drillings at some calderas in Japan and Mexico. The volume of the caldera deposit at Krakatau was estimated to be $10 \pm 3 \mathrm{~km}^{3}$ on the base of the gravity anomalies observed there by Yokoyama [1981]. However this calculation depends on the accuracy in the choice of the density contrast between the caldera deposit and the country rocks: the present author has theorized the density contrast as to be $150 \mathrm{~kg} / \mathrm{m}^{3}$ since the deposits have probably remained saturated and submerged in the sea. Consequently the bulk volume of the deposit is calculated as $13 \pm 3 \mathrm{~km}^{3}$. In 2005 2006 seismological tomographic imaging by Jaxybulatov et al. [2011] detected anomalously high $\mathrm{Vp} / \mathrm{Vs}$ ratios roughly at the location where the zone of caldera deposits have probably settled.

Magma reservoirs: At the Krakatau area, both temporal observations of two characteristics, S-wave attenuation and $\mathrm{Vp} / \mathrm{Vs}$ ratio, have been carried out by Harjono et al. [1989] and Jaxybulatov et al. [2011], respectively. The results indicate zones of S-wave attenuation at three depths, $5 \sim 10,8 \sim 13$ and $20 \mathrm{~km}$, directly beneath the Krakatau complex while zones of relatively high $\mathrm{Vp} /$ Vs ratio were detected at two levels, very shallow and roughly $10 \mathrm{~km}$ deep. The most probable zone of magma reservoir beneath the Krakatau Islands must be endowed with both the characters in common: that is the zone located at a depth of about $10 \mathrm{~km}$. These are schematically shown in Figure 5b: an assumed magma reservoir is labeled with a $\mathrm{Vp} / \mathrm{Vs}$ ratio 1.94 on an $\mathrm{S}$ wave attenuating zone. It may be plausible to speculate that this magma reservoir has the potential to have contributed to the 1883 caldera forming eruption with continuing influence on Anak Ktakatau since 1927.

Acknowledgements. The author owes much recent geophysical knowledge on the Krakatau complex to H. Harjono and his group for detection of magma bodies from anomalous shear waves, C. Deplus and his group for gravity and bathymetry data, and $\mathrm{K}$. Jaxybulatov and his group for seismological tomographic results. The author expresses his gratitude to these groups. The author gratefully acknowledges the help of Ms. Sara Tanaka who took some of her time to criticize the details of the present discussion. The author is thankfully benefited by the critical comments from anonymous referees on the earlier version of the manuscript.

\section{References}

Abe, K. (1992). Seismicity of the caldera making eruption of Mount Katmai, Alaska in 1912, B. Seismol. Soc. Am., 82, 175-191.

Ando, S. (1983). Structure of Nigori-gawa caldera deduced from the results of drillings, Chikyu, 5, 116- 
121 (in Japanese).

Aramaki, S. (1977). Basement of Aira caldera and eruption products of Sakurajima volcano, Report of the 2nd concentrated and synthetic observation of Sakurajima volcano, 105-119 (in Japanese).

Camus, G., A. Gourgaud and P.M. Vincent (1987). Petrological evolution of Krakatau (Indonesia): Implications for a future activity, J. Volcanol. Geoth. Res., 33, 299-316.

Carmichael, R.S. (1982). Handbook of physical properties of rocks, Vol. II, CRC Press, Inc. Roca Raton, Florida, 345 pp.

De la Cruz-Reyna, S., and I. Yokoyama (2011). A geophysical characterization of monogenetic volcanism, Geofís. Int., 50, 255-270.

Deplus, C., S. Bonvalot, D. Dahrin, M. Diament, H. Harjono and J. Dubois (1995). Inner structure of the Krakatau volcanic complex (Indonesia) from gravity and bathymetry data, J. Volcanol. Geoth. Res., 64, 23-52.

Escher, B.G. (1919). De Krakatau groep als vulkaan, Handel.van het Eerste Nederl. Ind. Natuur. Congr., 28-35.

Harjono, H., M. Diament, L. Nouaili and J. Dubois (1989). Detection of magma bodies beneath Krakatau volcano (Indonesia) from anomalous shear waves, J. Volcanol. Geoth. Res., 39, 335-348.

Jaeger, J.C. (1964). Elasticity, fracture and flow. London, Methuen \& Co. Ltd, 212 pp.

Jaxybulatov, K., I. Koulakov, M.I. Seht, K. Klinge, C. Reichert, B. Dahren and V.R. Troll (2011). Evidence for high fluid/melt content beneath Krakatau volcano (Indonesia) from local earthquake tomography, J. Volcanol. Geoth. Res., 206, 96-105.

Komazawa, M. (1995). Gravimetric analysis of Aso volcano and its interpretation, J. Geod. Soc. Jpn., 41, 17-45.

Kurozumi, H., and H. Doi (2003). Inner structure of the Nigorikawa caldera, Hokkaido, Japan, B. Volcanol. Soc. Jpn., 48, 259-274 (in Japanese with English abstract).

Morelli, C., C. Gantar, T. Honkasalo, R.K. McConnell, J.G. Tanner, B. Szabo, U. Uotila and C.T. Whalen (1974). The International Gravity Standardization Net 1971 (IGSN71), I.U.G.G.-I.A.G.-Publ.Spec. 4, Paris.

Nishida, Y., and I. Yokoyama (1965). A note on physical properties of boring cores dug at Kuttyaro caldera, Hokkaido, Geophys. Bull. Hokkaido Univ., 14, 5358 (in Japanese with English abstract).

Stehn, Ch.E. (1929). The geology and volcanism of the Krakatau group, Proc. Fourth Pacific Sci. Congr., Part I, 2-55.
Verbeek, R.D.M. (1885). Krakatau. Batavia, 546 pp.

Wharton, W.J.L. (1888). On the seismic sea waves caused by the eruption of Krakatoa, August 26th and 27th, 1883, In: The eruption of Krakatoa and subsequent phenomena, Roy. Soc., 89-151.

Yokoyama, I., and H. Tajima (1959). Gravity survey on the Kuttyaro caldera by means of a Worden gravimeter, Nature, 183, 739-740.

Yokoyama, I. (1963). Structure of calderas and gravity anomaly, B. Volcanol., 26, 67-72.

Yokoyama, I., and D. Hadikusumo (1969). Volcanological survey of Indonesian volcanoes. Part 3. A gravity survey on the Krakatau Islands, Indonesia, Bull. Earthq. Res. Inst., 47, 991-1001.

Yokoyama, I. (1981). A geophysical interpretation of the 1883 Krakatau eruption, J. Volcanol. Geoth. Res., 9, 359-378.

Yokoyama, I. (1987). A scenario of the 1883 Krakatau tsunami, J. Volcanol. Geoth. Res., 34, 123-132.

Yokoyama, I., and M. Mena (1991). Structure of La Primavera caldera, Jalisco, Mexico, deduced from gravity anomalies and drilling results, J. Volcanol. Geoth. Res., 47, 183-193.

Yokoyama, I. (2001). The largest magnitudes of earthquakes associated with some historical volcanic eruptions and their volcanological significance, Annali di Geofisica, 44, 1021-1029.

Yokoyama, I. (2013). Parasitic eruptions on Sakurajima Volcano, B. Volcanol. Soc. Jpn., 58, 91-102.

\footnotetext{
${ }^{\star}$ Corresponding author: Izumi Yokoyama, The Japan Academy, Ueno Park, Tokyo, Japan; email: iyokoyama@joy.ocn.ne.jp.

C 2014 by the Istituto Nazionale di Geofisica e Vulcanologia. All rights reserved.
} 